DOI 10.31718/2077-1096.19.3.146

UDC 615.099: 541.182.024: 616.8

Pervak M. $P$.

\title{
EFFECTS OF SILVER NANOPARTICLES ON PENTYLENETETRAZOL-INDUCED KINDLED SEIZURES IN RATS
}

Odessa National Medical University, Ukraine

Silver nanoparticles are used for delivering neurotropic agents to brain, increasing the bioavailability of insoluble drugs as well as for brain tumours treatment. Their effects upon brain excitability, especially under conditions of chronic epilepsy modelling are underinvestigated. The purpose of the study was to study the effects of silver nanoparticles upon pentylenetetrazol-induced kindled seizures in rats. Material and Methods. Experiments were performed on Wistar rats kindled during four weeks with pentylenetetrazol administrations in a dose of $30.0 \mathrm{mg} / \mathrm{kg}$, i.p. Only rats, which demonstrated generalized clonic-tonic seizures in a response to each of three last epileptogen injections, were included into the study. Nanoparticles and ionized argentum were administered in a dosage of $0.2 \mathrm{mg} / \mathrm{kg}$, i.p. Observation was performed in early and postponed period of kindling - in $24 \mathrm{~h}$ and three weeks from the moment of kindling induction, correspondently. Results and discussion. The calculation of the pentylenetetrazol dose, which effectively induced seizures in $50 \%$ of kindled rats $\left(E D_{50}\right)$, was performed in kindled animals in $24 \mathrm{~h}$ from the moment of last epileptogen administration was $22.0 \mathrm{mg} / \mathrm{kg}$. In postponed period of kindling (three weeks from the moment of last pentylenetetrazol administration in a dose of $30.0 \mathrm{mg} / \mathrm{kg}$, i.p.), ED $D_{50}$ of pentylenetetrazol was $16.0 \mathrm{mg} / \mathrm{kg}$. $E D_{50}$ of pentylenetetrazol, which induced clonic seizures in $50 \%$ animals at the early stage of kindling, was recalculated following the administration of ionized and nanoparticle forms of silver, and were less when compared with such ones determined in the control group by $13.5 \%(P>0,05)$ and $26.0 \%$ $(P<0,05)$, respectively. In the postponed period of kindling $E D_{50}$ of ionized and nanoparticle forms of silver were less when compared with control by $20.0 \%(P<0.05)$ and by $42.0 \%$, respectively $(P<0.05)$. Significant difference was noted between groups treated with ionized and nanoparticle silver $(P<0.05)$. The net intensification of pentylenetetrazol seizure manifestations was seen in kindled rats treated with silver nanoparticles, when seizure discharges amplitude achieved 1.0-1.2 $\mathrm{mV}$ and frequency of 3/sec, which exceeded the ones in rats treated with ionized silver. Conclusion. Silver nanoparticles induce the increase in seizures severity in pentylenetetrazol-kindled rats, and this effect was more pronounced at the postponed stage of kindling development.

Key words: silver nanoparticles, chemical kindling, seizures, pentylenetetrazol.

Present research in the context of the research project plan, programs and department themes. The study was carried out in accordance with the research project "Epigenetic mechanisms of factors of physic nature action on brain structures and homeostasis", state registration number $0116 \cup 008928$.

\section{Introduction}

Nanotechnologies have been found to possess a great potential in the treatment of some diseases affecting brain tissue [1, 2]. Namely metal nanoparticles has been proven as an effective mean in the course of brain tumour treatment [1]; neurotropic agents being encapsulated in polymeric nanoparticles show good bioavailability and are able to penetrate blood-brain barrier (BBB) effectively [3]. It has been shown that water insoluble antiepileptic drugs as nanoparticles display excellent pharmacokinetics during systemic administration [3].

Phenytoin-contained liposomes demonstrate high level of antiseizure activity on modelled seizures induced with CAMP/EDTA in rats, and nanoparticles of blocker of NMDA receptor MRZ 2/576 exceed antiseizure activity of this compound delivered in free form in 10 times [3]. It has been shown that clonazepam being incorporated into solid lipid nanoparticles demonstrates better penetration through BBB and marked ability to prevent pentylenetetrazol-induced generalized seizures [2]. But the penetration worsened for clonazepam in mixed micelles form as well as antiseizure activity was also reduced.

The perspectives of further investigations of antiseizure effectiveness of nanoparticles should include models of chronic epilepsy, and namely pentylenetetrazol (PTZ)-induced kindling, which resembles main features of clinical forms of epilepsy [4].

Hence, the purpose of the study was to study the effects of silver nanoparticles on seizures induced in PTZ-kindled rats.

\section{Material and methods}

Experiments were performed on Wistar male rats (180-270 g). They were kept under standard laboratory conditions, i.e. constant temperature of $23^{\circ} \mathrm{C}, 60 \%$ relative humidity, $12-\mathrm{h}$ dark/light cycles, standard diet and tap water was present ad libitum. Procedures involving animals and their care were conducted according to Odessa National Medical University ethical committee guidelines (Protocol № 84 dated 10 Oct. 2008) that comply with international laws and policies [European Community Council Directive 86/609, OJ L 358, I, December 12, 1987; National Institute of Health Guide for Care and Use of Laboratory Animals, US National Research Council, 1996].

Registration electrodes were implanted under Nembutal anesthesia ("Ceva", France, 40 mg/kg, i.p.): two into frontal and two into occipital regions in 
both hemispheres (coordinates: $A P=1.2 ; \quad L=3.0$; $\mathrm{H}=1.0$ and $\mathrm{AP}=7.8 ; \mathrm{L}=3.0 ; \mathrm{H}=1.0$ correspondently) and into ventral hippocampus ( $\mathrm{AP}=-4.3 ; \mathrm{L}=4.5$; $\mathrm{H}=8.0$ ) [5]. Indifferent electrode was placed into nasal bones. Electrodes were fixed to the skull with dental cement. Starting one week after surgery, the rats were handled daily and adapted to the experimental setup. Monopolar EEG registration was started on the $7^{\text {th }}-14^{\text {th }}$ day from the moment of operation on "DX-5000" computer electroencephalograph (Charkiv, Ukraine).

Kindling in rats was induced using a subthreshold dose of PTZ (35.0 mg/kg, i.p.) ("Sigma Aldrich", USA) starting on the $10^{\text {th }}-14^{\text {th }}$ day following the surgery. The total of 21 injections with the epileptogen was given. Those animals, which demonstrated generalized clonic-tonic seizures as a response to each of the last three times of PTZ administration, were included into the study. Testing of behavioral reactions was conducted at 9:00 a.m. - 12:00 p.m., in 24 hours and in three weeks after the last kindling administration of PTZ early and postponed period correspondently.

Thus, the rats were divided into the following groups:

Control group - animals with PTZ-induced kindling treated i.p. with $0.9 \%$ saline solution (10 rats);

The second control group - kindled with PTZ and treated with $2.0 \%$ colloid solution of ionized argentum (30 rats);

The third group - kindled with PTZ and treated with silver nanoparticles $(30 \mathrm{~nm})$, which were got via citrate method [6] (10 rats). The size of nanoparticles was controlled with the spectrometric absorption of light at $413 \mathrm{~nm}$ characteristic for the nanoparticles with the diameter of $30 \mathrm{~nm}$ [6]. Nanoparticles and ionized silver were administered in a dosage of $0.2 \mathrm{mg} / \mathrm{kg}$, i.p. [7].

The synthesis of silver nanoparticles was performed under the next parameters:

- equimolar concentrations of $\mathrm{AgNO}_{3}$ and $\mathrm{Na}_{3} \mathrm{C}_{6} \mathrm{H}_{5} \mathrm{O}_{7}: 5 \times 10-4 \mathrm{M}$;

- the concentrations ratio between $\mathrm{AgNO}_{3}$ and $\mathrm{Na}_{3} \mathrm{C}_{6} \mathrm{H}_{5} \mathrm{O}_{7}$ was 1:4;

- temperature of synthesis was $100^{\circ} \mathrm{C}$;

- period of synthesis was $60 \mathrm{~min}$.

$E D_{50}$, of PTZ, which were able to induce clonic seizures in $50 \%$ of experimental animals were determined during early and postponed periods of kindling; and the same indices under conditions of nanoparticles administration were verified as well.

Values were compared using one-way analysis of variance followed by a post hoc $t$-test. Values were presented as mean \pm standard mean deviation, with findings of $P<0.05$ considered as significant.

\section{Reuslts and discussion}

The calculation of the PTZ dose, which was sufficient to induced seizures in $50 \%$ of kindled rats $\left(E D_{50}\right)$, was performed in kindled animals in $24 \mathrm{~h}$ from the moment of last epileptogen administration. It was established that after PTZ injection in a dose of $20.0 \mathrm{mg} / \mathrm{kg}$, clonic seizures were registered in 3 out of 12 rats, and in two rats the generalized seizure fits were precipitated later on. The increasing of the PTZ dosage up to $25.0 \mathrm{mg} / \mathrm{kg}$ was followed by clonic seizures development in 8 out of 10 kindled rats, and in 5 out of them generalized seizure fits were registered. Hence, $E D_{50}$ of PTZ was $22.0 \mathrm{mg} / \mathrm{kg}$.

Injection of PTZ in the dosage of $15.0 \mathrm{mg} / \mathrm{kg}$, i.p. in postponed period of kindling (three weeks from the moment of last PTZ administration in a dosage of $30.0 \mathrm{mg} / \mathrm{kg}$, i.p.) was followed by clonic seizures development in half of experimental animals (4 rats). It should be highlighted that in 3 out of 4 those rats the generalized seizure fits were precipitated. Higher dosage of PTZ $(25.0 \mathrm{mg} / \mathrm{kg}$, i.p.) induced seizure reactions in more than $90 \%$ of kindled animals, and prevalent number of them (8 out of 10) demonstrated generalized clonic-tonic fits. Hence, $E D_{50}$ of PTZ in postponed period of kindling was $16.0 \mathrm{mg} / \mathrm{kg}$. This value was reduced by $27.2 \%$ when compared with that, which was observed at the beginning of kindling modelling $(P<0.05)$.

$\mathrm{ED}_{50}$ of PTZ, which induced clonic seizures in $50 \%$ animals at the early stage of kindling and was recalculated after the administration of ionized and nanoparticle forms of silver were less when compared with such one determined in the control group by $13.5 \%(P>0.05)$ and $26.0 \%(P<0.05)$ correspondently (Fig. 1).

In the postponed period of kindling, $\mathrm{ED}_{50}$ of PTZ, which induced clonic seizures in $50 \%$ animals after administration of ionized and nanoparticle forms of silver, were less when compared with control by $20.0 \%(P<0.05)$ and by $42.0 \%(P<0.05)$ (Fig. 1$)$. There was a significant reduction of investigated index in comparison with the rats treated with ionized silver $(P<0.05)$.

EEG investigations revealed the appearance of spike-wave complexes with amplitude of $150-250$ $\mathrm{mcV}$ and frequency of generation $7-11 / \mathrm{sec}$ in 5.07.5 min from the moment of PTZ administration in a dose of $E D_{50}(22.0 \mathrm{mg} / \mathrm{kg}$, i.p., $24 \mathrm{~h}$ from the last kindled injection of epileptogen). During the next 5.0-10.0 min spike epileptic discharges were registered, which amplitude ranged from 0.2 up to $0.7 \mathrm{mV}$ and frequency of generation from 15 to 30 per min (Fig. 2, A).These presentations correlated with clonic seizures. 


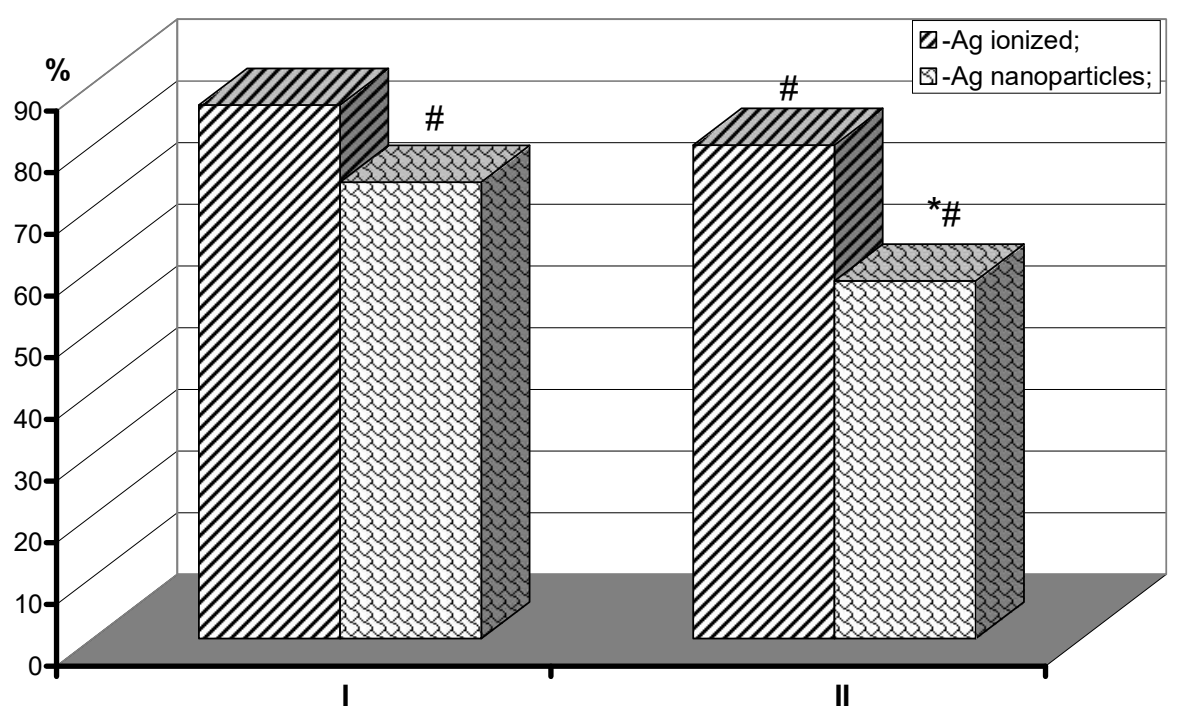

Fig. 1. $E D_{50}$ of PTZ, which is able to induce clonic seizures in $50 \%$ of kindled animals treated with different forms of silver ( $\mathrm{Ag}$ ).

Notes: abscissa - I- ED 50 determined in $24 \mathrm{~h}$ from the last kindled seizure;

II- $E D_{50}$ in three weeks from the last kindled seizure. Ordinate: $E D_{50}$

in \% pertained to its value in control group (kindled rats treated with saline solution - $100 \%$ ).

$\#-P<0.05$ when compared with the control group;

${ }^{*}-<0.05$ when compared with the group of rats treated with ionized Ag.

The identical scheme of PTZ administration $(22.0 \mathrm{mg} / \mathrm{kg}$, i.p.), following the administration of silver nanoparticles, was followed by appearance of spike potentials with amplitude of $200-500 \mathrm{mcV}$ and frequency of generation 15-25 per min in 2.5-5.0 min. Their amplitude and frequency rose during next $10 \mathrm{~min}$ up to $1.0-1.2 \mathrm{mV}$ and $3 / \mathrm{s}$ correspondently (Fig. 2, B). Such presentations were registered in all investigated brain structures during the following 20.0-40.0 min of observation. The generalized clonic-tonic seizure fits were registered during such synchronized EEG activity with postseizure depression. 3 out of 9 rats died of repeated seizure fits.

Hence, the obtained data revealed that under conditions of PTZ-induced kindling the net increasing of epileptic activity was observed following the administration of silver nanoparticles. Intensification of seizures was registered in the form of decreasing of $E D_{50}$ dose of PTZ, which caused the clonic seizures in $50 \%$ of kindled animals. The effect of facilitation of seizures was more pronounced in postponed kindled state known as resistant and more severe form of chronic brain epileptisation [4]. Administration of silver nanoparticles reduced $\mathrm{ED}_{50}$ of PTZ by $42.0 \%$, and this reduction significantly (by $22.0 \%$ ) exceeded the reduction, which was observed in rats treated with ionized form of silver.

We should also note that ionized silver was also able to cause subtle proepileptogenic effects in postponed kindled period, which might be explained by the presence of some amount of nanoparticle form of silver in colloid silver solution [7]. Facilitation of seizure activity induced with silver nanoparticles might be explained by their induction of mitogenactivated protein-kinases [8], as well as byoxidative stress and apoptosis activation $[9,10]$.

The possible increasing of penetration of bloodbrain barrier, as a result of silver nanoparticle effects, which underlay facilitative action on PTZ seizures, might be used for better delivering antiepileptic drugs to brain tissue.

\section{Conclusion}

Silver nanoparticles are able to cause the increase in seizures severity in PTZ-kindled rats, and this effect is more pronounced during postponed stage of kindling development.

\section{The perspectives for further research}

It is planned to clarify facilitative effects of silver nanoparticles upon kindled epileptiform activity. 

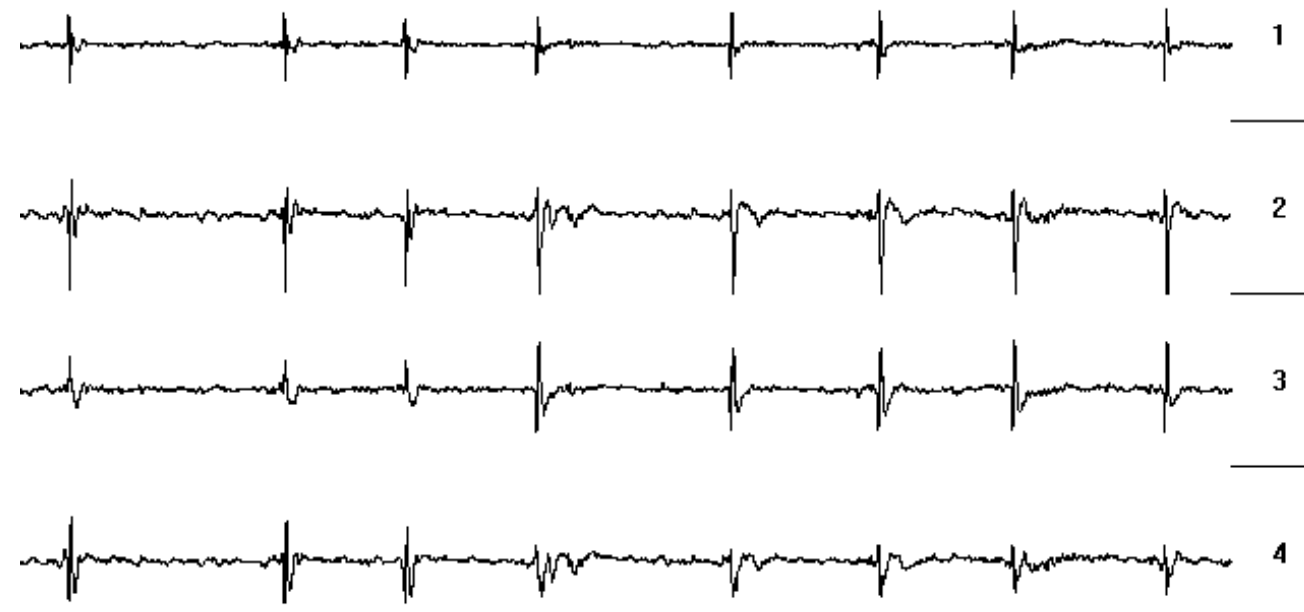

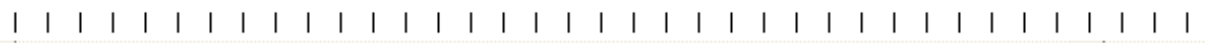

$A$
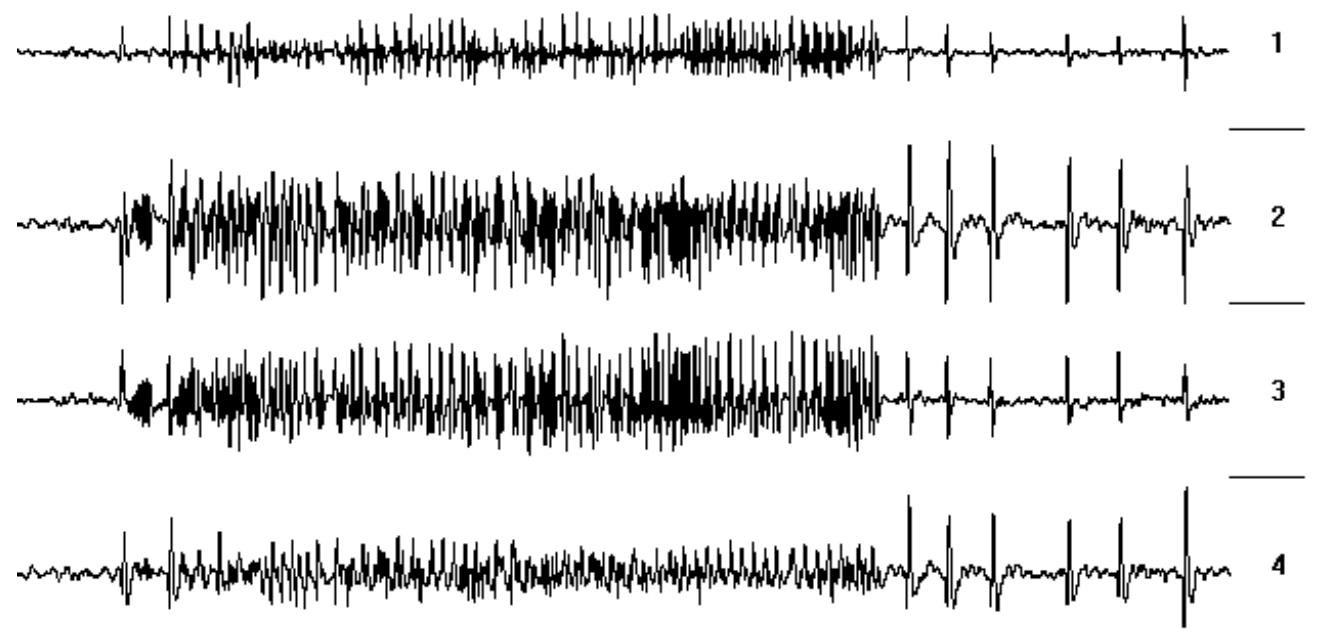

$\begin{array}{llllllllllllllllllllllllllllllllllll}1 & 1 & 1 & 1 & 1 & 1 & 1 & 1 & 1 & 1 & 1 & 1 & 1 & 1 & 1 & 1 & 1 & 1 & 1 & 1 & 1 & 1 & 1 & 1 & 1 & 1 & 1 & 1 & 1 & 1 & 1 & 1 & 1 & 1 & 1 & 1\end{array}$

Fig. 2. Eletcrographic manisfestations in rats treated with silver nanoparticles.

Notes: A: $12,5 \mathrm{~min}$ from the moment of PTZ administration (30,0 $\mathrm{mg} / \mathrm{kg}$, i.p.) to control rat (saline treated).

B: 10,0 from the moment of PTZ administration $(30,0 \mathrm{mg} / \mathrm{kg}$, i.p.) to the kindled rat treated with silver nanoparticles.

1 - left frontal cortex, 3- left, and 4- right ventral hippocampus, 4- left occipital cortex.

The distance between left horizontal lines $-1,0 \mathrm{mV}$, the distance between bottom vertical lines - $1 \mathrm{~s}$.

\section{References}

1. Ruan S, Hu C, Tang X, Cun X, Xiao W, Shi K, et al. Increased Gold Nanoparticle Retention in Brain Tumors by in Situ EnzymeInduced Aggregation. ACS Nano. 2016; 10(11): 10086-98. PMID: 27934068. doi: 10.1021/acsnano.6b05070

2. Leyva-Gomez G Gonzalez-Trujano ME Lopez-Ruiz E, Couraud PO, Wekslerq improves the anticonvulsant effect of clonazepam on the improves the anticonvulsant effect of clonazepam on the
pentylenetetrazole-induced
seizures: pentylenetetrazole-induced seizures: behavior and
electroencephalogram. J of Pharm Sci. 2014; 103(8): 2509-19. electroencephalogram. J of Pharm Sci.

3. Lason W. Perspectives of nanotechnology in epilepsy treatment. J of Epileptology. 2010; 18(2): 81-5. doi: 10.1016/S17341140(10)70292-9

4. Shandra AA, Godlevskyy LS, Brusnetsov AY. Kyndlyng y epyleptycheskaya aktyvnost [Kindling and epileptic activity]. Odessa: Astroprynt, 1999. 191 p. [Russian]

5. Paxinos G, Watson C. The Rat Brain in Stereotaxic Coordinates. Sydney: Academic Press Inc; 1998. 456 p.

6. Syrma EY, Skobeeva VM, Ulyanov VA. Morfofunktsyonalnaya kharakterystyka dermy kozhy pry vvedenyy nanochastyts serebra
[Morphological and functional characteristics of the dermis of the skin with the introduction of silver nanoparticles] Visnyk morfologiyi. 2014; 2: 245-8. [Russian]

7. Qin G, Tang $S$, Li S, Lu H, Wang $Y$ Z Zhao $P$ et al. Toxicological evaluation of silver nanoparticles and silver nitrate in rats following 28 days of repeated oral exposure. Environ Toxicol. 2017; 32(2): 609-18. PMID: 26996539. doi: 10.1002/tox.22263

8. Jiao ZH, Li M, Feng YX, Shi JS, Zhang J, Shao B, et al. Hormesis effects of silver nanoparticles at non-cytotoxic doses to human hepatoma cells. PLOS ONE. 2014; 9(7): e102564. PMID: 25033410. PMCID: PMC4102499. doi: 10.1371/journal.pone.0102564

9. Li Y, Guo M, Lin Z, Zhao M, Xiao M, Wang $C$, et al. Polyethylenimine- functionalized silver nanoparticle-based codelivery of paclitaxel to induce HepG2 cell apoptosis. Int $\mathrm{J}$ Nanomedicine. 2016; 11: 6693-702. PMID: 27994465. PMCID: PMC5154725. doi: 10.2147/IJN.S122666

10. Dayem AA, Kim B, Gurunathan S, Choi HY, Yang G, Saha SK, et al. Biologically synthesized silver nanoparticles induce neuronal differentiation of SH-SY5Y cells via modulation of reactive oxygen differentiation of SH-SY5Y cells via modulation of reactive oxygen
species, phosphatases, and kinase signaling pathways. Biotechnol species, phosphatases, and kinase signaling pathways. Biotechnol
J. 2014; 9: 934-43. PMID: 24827677 . doi: 10.1002/biot.201400555 


\begin{abstract}
Реферат
ВПЛИВ НАНОЧАСТОЧОК СРІБЛА НА КІНДЛІНГОВІ СУДОМИ, ІНДУКОВАНІ У ЩУРІВ ВВЕДЕННЯМИ ПЕНТИЛЕНЕТЕТРАЗОЛУ Первак М. П.

Ключові слова: наночасточки срібла, хімічний кіндлінг, судоми, пентиленететразол.

Наночасточки срібла застосовують з метою забезпечення біодоступності препаратів, які погано проникають через гематоенцефалічний бар'єр, для прецизійної деструкції пухлин мозку. Тому актуальним є завдання вивчення їх впливу на збудливість головного мозку. Метою дійсного дослідження було вивчення особливостей судомних реакцій у щурів із хронічною формою епілептизації мозку, викликаної методом кіндлінгу за умов застосування наночасточок срібла. У щурів лінії Вістар однократними щодобовими уведеннями пентиленететразолу в дозі 30,0 мг/кг, в/очер протягом трьох тижнів викликали генералізовані клоніко-тонічні судоми. В ранньому та віддаленому періодах кіндлінгу (відповідно через 24 г та три тижні з момента останнього введення пентиленететразолу) вводили наночасточки срібла, синтезовані цитратним методом (0,2 мг/кг, в/очер), а також розчин іонізованого срібла $(0,2$ мг/кг, в/очер) з наступним застосуванням тестуючої дози епілептогену. $\mathrm{ED}_{50}$ пентиленететразолу в ранньому та віддаленому періодах кіндлінга склали 22,0 і 16,0 мг/кг відповідно. Застосування наночасточок срібла знижувало $\mathrm{ED}_{50}$ в ранньому періоді кіндлінга на $26,0 \%(\mathrm{P}<0,05)$ і в пізньому - на $42,0 \%$ $(P<0,05)$, в той час як застосування іонізованого срібла викликало зниження $E D_{50}$ на $13,5 \%(P>0,05)$ i на $20,0 \%(P<0,05)$ відповідно. Спостерігалось також достовірне зниження $\mathrm{ED}_{50}$ в групі із застосуванням наночасточок у порівнянні до групи щурів, яким вводили іонізоване срібло $(P<0,05)$. Під впливом наночасточок срібла значно зростала амплітуда та частота судомних розрядів - до 1,0-1,2 мВ та 3/сек відповідно. Застосування наночасточок срібла викликає зростання тяжкості судомних проявів у тварин із пентиленететразолу -кіндлінгом, яке є більш виразним у віддаленому періоді його розвитку.
\end{abstract}

\title{
Реферат
}

ВЛИЯНИЕ НАНОЧАСТИЦ СЕРЕБРА НА КИНДЛИНГОВЫЕ СУДОРОГИ, ИНДУЦИРОВАННЫЕ У КРЫС ВВЕДЕНИЯМИ ПЕНТИЛЕНЕТЕТРАЗОЛА

Первак М. П.

Ключевые слова: наночастицы серебра, химический киндлинг, судороги, пентиленететразол.

Наночастицы серебра применяют для обеспечения биодоступности препаратов, которые не проходят через гематоэнцефралический барьер, для избирательной деструкции опухолей мозга. Поэтому актуальной является задача изучения их влияния на возбудимость головного мозга. Целью настоящего исследования было изучение особенностей судорожных реакций у крыс с хронической формой эпилептизации мозга, вызванной методом киндлинга в условиях применения наночастиц серебра. У крыс линии Вистар однократными ежедневными введениями пентиленететразола (30,0 мг/кг, в/бр) в течение трех недель вызвали генерализованные клонико-тонические судороги. В раннем и отдаленном периодах киндлинга (24 ч и три недели с момента последнего введения пентиленететразола) животным вводили наночастицы серебра, синтезированные цитратным методом (0,2 мг/кг, в/бр), а также раствор ионизированного серебра (0,2 мг/кг, в/бр) с последующим применением тестирующей дозы пентиленететразола. $E D_{50}$ пентиленететразола в раннем и позднем периоде киндлинга составила 22,0 и 16,0 мг/кг соответственно. Применение наночастиц серебра снижало $\mathrm{ED}_{50}$ в раннем периоде киндлинга на $26,0 \%$ $(P<0,05)$ и в позднем - на 42,0\% $(P<0,05)$, в то время как применение ионизированного серебра вызывало снижение $\mathrm{ED}_{50}$ на $13,5 \%(P>0,05)$ и на $20,0 \%(P<0,05)$ соответственно. При этом отмечались достоверное снижение $\mathrm{ED}_{50}$ в группе с применением наночастиц в сравнении с группой, которым применяли ионизированное серебро $(\mathrm{P}<0,05)$. Также под влиянием наночастиц серебра значительно увеличивалась амплитуда и частота судорожных разрядов - до 1,0-1,2 мВ и 3/сек соответственно. Применение наночастиц серебра вызывает увеличение тяжести судорожных проявлений у животных с пентиленететразола-киндлингом, более выраженное в отдаленном периоде его развития. 